\title{
PERMASALAHAN INDUSTRI KECIL PASCAGEMPA BUMI: SURVEI PADA BEBERAPA INDUSTRI DI KABUPATEN KLATEN, JAWA TENGAH
}

\author{
P. Didit Kresnadewara \\ Y. Sri Susilo \\ Universitas Atma Jaya Yogyakarta
}

\begin{abstract}
The purpose of this research is to recognize and analyze the problems that small industries face due to the earthquake disaster in Klaten Region, Central Java. The problems include damages, entrepreneurs/craftsmen's anxieties, and entrepreneurs/craftsmen's' urgent needs. Data is compiled by field survey and in-depth interview. Small industries that were surveyed were readymade wear industry, earthenware vessels and ceramics industry, furniture industry, woven cloth industry, and roof-tiles industry. Datas are analyzed with descriptive analysis method. The result of the survey is that damages occurred especially on buildings, production tools/equipments, and market potency. The entrepreneurs/craftsmen's anxieties are the loss/decrease of customers, the disturbance of production and distribution process, lack of ability to afford the financial obligations, and have to lay off the employees. And third; the urgent needs are building repair, tool/equipment repair, and additional business capital. Finally, this research talks about time of business recovery estimation.
\end{abstract}

Keywords: business problems, small industry, post-earthquake, Klaten Region

\section{PENDAHULUAN}

Gempa bumi tektonik yang terjadi pada tanggal 27 Mei 2006 di wilayah Propinsi Daerah Istimewa Yogyakarta (DIY) dan Kabupaten Klaten (Jawa Tengah) telah melumpuhkan aktivitas industri di wilayah tersebut, termasuk industri skala kecil dan menengah (Kuncoro, 2006a). Sentra-sentra industri di wilayah Propinsi DIY dan Propinsi Jawa Tengah, termasuk Kabupaten Klaten terancam tidak dapat berproduksi lagi. Hal ini dikarenakan gempa telah menghancurkan sarana dan prasarana industri di sentra-sentra tersebut. Gempa tersebut juga telah merusak rumah penduduk, sekolah, perkantoran, dan fasilitas umum lainnya.

Estimasi yang dilakukan oleh World Bank menyebutkan kerusakan dan kerugian yang disebabkan oleh gempa bumi di wilayah Propinsi DIY dan Kabupaten Klaten (Jawa Tengah) ini mencapai nilai lebih kurang Rp 29 Triliun (Bappenas et al., 2006). Sedangkan kerusakan pada sektor industri kecil dan menengah (IKM) mencapai Rp 7,7 trilyun. Sumber yang lain menyebutkan kerusakan IKM di Kabupaten Klaten mencapai 3.919 unit usaha dengan nilai kerusakan sekitar Rp 222,9 milyar. Jumlah tersebut sebanyak 2.821 unit usaha mengalami rusak berat dan 1.178 unit usaha rusak ringan ${ }^{1}$. Kerusakan tersebut mencakup bangunan, peralatan kerja, dan modal kerja untuk melaksanakan kegiatan produksi. Jumlah seluruh unit usaha IKM di Kabupaten Klaten,

1 Berdasarkan data Ditjen Industri Kecil dan Menengah, Departemen Perindustrian per tanggal 8 Juni 2006 Untuk wilayah Propinsi DIY jumlah IKM di wilayah gempa sebanyak 2.783 unit usaha, dari jumlah tersebut yang mengalami rusak berat sebanyak 2.140 unit usaha, 40 unit usaha rusak sedang, dan 178 unit rusak ringan (http://rehabyogyajateng.bappenas.go.id). Kriteria rusak berat: $>50 \%$ rusak / bangunan roboh, rusak ringan 25\% - 49\% rusak, dan rusak ringan: < 25\% rusak (bangunan, peralatan produksi, dan modal kerja). Untuk Usaha Mikro, Kecil, dan Menengah (UMKM) di Propinsi DIY dan Jateng mencapai 29.169 unit usaha dan lebih 654.000 tenaga kerja yang terancam PHK. 
khususnya di wilayah yang terkena gempa yaitu Kecamatan Prambanan. Kecamatan Gantiwarno, Kecamatan Jogonalan, Kecamatan Wedi, Kecamatan Bayat, Kecamatan Cawas, Kecamatan Trucuk, Kecamatan Juwiring, dan Kecamatan Pedan, sebanyak 4.093 unit usaha².

Berkaitan dengan hal tersebut, fokus dalam tulisan ini adalah menjawab pertanyaan bagaimanakah permasalahan yang dihadapi pengusaha / pengrajin industri kecil di Kabupaten Klaten pascagempa bumi yang terjadi pada tanggal 27 Mei 2006? Permasalahan dalam kasus ini mencakup komposisi kerusakan pasacagempa, bentuk kekhawatiran yang dialami oleh pengusaha / pengrajin, kebutuhan yang dianggap mendesak oleh pengusaha / pengrajin, dan perkiraan waktu pemulihan (recovery) ${ }^{3}$.

Sistematika penulisan terdiri dari 5 (lima) bagian. Setelah bagian pendahuluan, dilanjutkan dengan bagian kedua yaitu riset / studi terkait. Bagian ketiga adalah metode penelitian yang digunakan dalam riset. Bagian selanjutnya adalah hasil dan pembahasan dari survei. Pada bagian terakhir berisi catatan penutup untuk melengkapi tulisan ini.

\section{TINJAUAN LITERATUR}

\section{1. Studi Terkait}

Sri Susilo (2005) melakukan riset pada pedagang warung angkringan di Kota Yogyakarta. Responden yang dipilih sebanyak 50 pedagang warung angkringan yang berlokasi di wilayah seputar Beteng Keraton Yogyakarta. Metode pengumpulan data dilakukan dengan survei lapangan dan wawancara. Metode analisis yang digunakan dalam studi adalah analisis deskriptif. Fokus dalam riset ini terutama menyangkut masalah yang dihadapi pedagang angkringan dan strategi yang dilakukan agar usahanya mampu bertahan.

Masalah yang dihadapi pedagang warung angkringan pada umumnya adalah masalah modal dan lokasi usaha. Terbatasnya modal yang dimiliki, terutama modal awal, membuat sebagian pedagang warung angkringan menjadi pedagang "non mandiri", yaitu pedagang yang belum mempunyai gerobag sendiri dan seluruh barang dagangan dipasok oleh orang lain atau juragan ${ }^{4}$. Keberadaan usaha pedagang warung angkringan terkait erat dengan lokasi usaha. Lokasi usaha mereka pada umumnya di pinggir jalan atau trotoar, dengan demikian dimungkinkan sewaktu-waktu mereka digusur oleh pihak aparat pemerintah.

Studi mengenai masalah dan dinamika industri kecil dan kerajinan rumah tangga (IKKRT) pasca krisis ekonomi 1998 dilakukan oleh Sri Susilo dan Sutarta (2004). Penelitian yang menggunakan sampel 6 kelompok industri kecil yaitu: (1) industri pengolahan makanan, (2) industri pakaian jadi, (3) industri mebel kayu, (4) Industri kerajinan kulit, (5) industri gerabah, dan (6) industri kerajinan lainnya. Lokasi penelitian mencakup wilayah Yogyakarta dan Surakarta. Metode analisis yang digunakan adalah dengan analisis deskriptif.

Hasil studi tersebut adalah permasalahan yang dihadapi oleh IKKRT antara jenis atau kelompok industri yang satu dengan yang lainnya mempunyai persamaan namun juga mempunyai perbedaan. Persamaan yang menonjol adalah permasalahan kenaikan harga faktor produksi yang memaksa mereka menaikkan harga jual produk. Hal yang sama lainnya adalah menurunnya tingkat produksi dan employment. Dalam hal perbedaan permasalahan pokok yang dihadapi

2 Berdasarkan data tahun 2005, di Kabupaten Klaten terdapat 35.928 unit usaha industri. Dari jumlah tersebut $99,65 \%$ merupakan industri kecil yang memperkerjakan 145.270 orang, sedangkan industri menengah dan besar memperkerjakan 11.125 tenaga kerja (Ari/Litbang Kompas, 2006).

3 Cakupan masalah ini mengacu pada survei yang dilakukan oleh PPE Fakultas Ekonomi UAD, PPE Fakultas Ekonomi UMY (lihat misalnya Kurniawan, 2006; Bank Indonesia, 2006), dengan tujuan hasilnya dapat dibandingkan.

4 Di samping itu juga ada pedagang yang termasuk "semi mandiri", yaitu pedagang yang sudah mempunyai gerobag sendiri namun barang dagangannya masih dipasok oleh orang lain / juragan. Untuk pedagang yang mempunyai gerobag dan menyiapkan barang dagangan sendiri disebut pedagang "mandiri". 
tergantung dari jenis dan karakteristik masing-masing IKKRT. Ada yang menyatakan masalah pokok mereka adalah pasokan bahan baku, namun ada yang menyatakan masalah pokok yang dihadapi adalah kemampuan bersaing di pasar. Ada juga produsen IKKRT yang menyatakan masalah pokok mereka adalah pemasaran produk, dan juga ketersediaan tenaga kerja terampil.

Selanjutnya studi Sri Susilo dan Sri Handoko (2002) menunjukkan bahwa dampak krisis ekonomi tahun 1997 - 1998 menyebabkan unit usaha industri kecil dan kerajinan rumah tangga (IKKRT) menghadapi masalah penurunan jumlah produksi dan kesempatan kerja. Unit usaha IKKRT yang menjadi sampel adalah: (1) industri pembuatan tempe, (2) industri pakaian jadi, (3) industri pembuatan mebel kayu, (4) industri pengecoran logam, (5) industri kerajinan kulit, dan (6) industri kerajinan gerabah dan keramik. Penurunan produksi yang terjadi antara $10 \%-60 \%$. Sedangkan kesempatan kerja mengalami penurunan antara 10\%-50\%. Penurunan produksi dan kesempatan kerja yang paling besar adalah pada industri pengecoran logam. Unit usaha IKKRT yang disurvei adalah unit usaha yang berlokasi di sebagian wilayah Propinsi DIY dan Kabupaten Klaten.

Faktor penyebab menurunnya produksi dan employment tersebut terutama disebabkan oleh naiknya harga bahan baku dan menurunnya permintaan pasar. Untuk mengatasi hal tersebut pengusaha pada umumnya dihadapkan pada pilihan pada menaikkan harga barang atau mengurangi "kualitas" produk dengan tetap mempertahankan harga jual. Dalam studi ini juga terungkap masalah dan dinamika yang dihadapi IKKRT perbedaan namun juga ada persamaannya.

\section{METODA PENELITIAN}

\subsection{Lokasi Penelitian}

Penelitian dilakukan di beberapa pusat / sentra Industri di Kabupaten Klaten, Propinsi Jawa Tengah yang terkena dampak langsung gempa bumi (lihat Pemda DIY dan Pemda Jateng, 2006). Sentra-sentra industri termaksud dan jumlah responden yang disajikan pada Tabel 1.

\section{Tabel 1}

\section{Sentra Industri dan Jumlah}

\begin{tabular}{clc}
\hline No. & \multicolumn{1}{c}{ Sentra Industri } & $\begin{array}{c}\text { Jumlah } \\
\text { Responden }\end{array}$ \\
\hline 1. & Pakaian Jadi, Wedi & 12 \\
2. & Pakaian Jadi, Gantiwarno & 8 \\
3. & Mebel Kayu, Trucuk & 8 \\
4. & Mebel Kayu, Juwiring & 12 \\
5. & Genteng, Cawas & 8 \\
6. & Kain Tenun, Cawas & 12 \\
7. & Gerabah, Bayat $\quad$ Jumlah & 10 \\
& & $\mathbf{7 0}$ \\
\hline
\end{tabular}

Sumber: Hasil survey (diolah)

\subsection{Tahapan/Langkah Penelitian}

Adapun tahapan / langkah penelitian sebagai berikut: pertama, melakukan pengumpulan data sekunder / referensi dari instansi / lembaga yang telah disebutkan di atas. Sumber data sekunder / referensi lainnya bersumber dari majalah, surat kabar, jurnal, publikasi lainnya serta penelusuran melalui teknologi informasi; kedua, melakukan survei terhadap 70 (tujuh puluh) pengusaha / pengrajin industri kecil untuk mencari data dan informasi yang sesuai dengan tujuan studi. Survei dilakukan dengan cara melakukan wawancara berdasarkan kuesioner yang telah disiapkan. Secara keseluruhan kegiatan survei lapangan dilakukan pada bulan bulan Agustus 2006. Metode yang dipilih untuk menentukan sampel adalah purposive sampling (Sekaran, 2003); 
ketiga, melakukan wawancara mendalam terhadap 5 (lima) responden yang mewakili unsur pengurus kelompok pengusaha / pengrajin, wakil dari pengusaha / pengrajin industri kecil sendiri, serta wakil Disperindagkop dan Penanaman Modal Kabupaten Klaten. Tujuan dilakukan wawancara mendalam agar diperoleh informasi yang lebih mendalam dan informasi lain yang tercakup dalam kuesioner; keempat, dari data primer dan sekunder yang terkumpul, kemudian diolah dan dinalisis sesuai dengan tujuan penelitian; dan kelima, penulisan laporan hasil riset, presentasi hasil penelitian, revisi laporan penelitian, dan publikasi hasil riset dalam jurnal terakreditasi.

\subsection{Alat Analisis}

Analisis dalam penelitian ini dilakukan dengan pendekatan deskriptif. Dalam analisis deskriptif dilakukan interpretasi atas data dan hubungan yang ada dalam penelitian tersebut. Di samping itu juga dilakukan komparasi antara hasil penelitian dengan hasil-hasil penelitian terkait dan dilakukan korelasi antara hasil-hasil penelitian tersebut dengan teori atau konsep yang relevan (Singarimbun dan Effendi, 1989). Selanjutnya analisis secara deskriptif dapat juga dilakukan dengan teknik statistik yang relatif sederhana, seperti misalnya menggunakan tabel, grafik, dan ukuran tendensi sentral yaitu nilai rata-rata, nilai tengah, dan modus (Kountur, 2003). Dengan mengacu pada pengertian analisis deskriptif tersebut maka sekalipun metode analisis yang digunakan dalam riset ini relatif sederhana, namun dapat memberikan informasi yang memadai sesuai dengan tujuan penelitian.

Penelitian ini menggunakan batasan operasional sebagai berikut: 1) Industri kecil adalah pengusaha atau pengrajin yang melakukan kegiatan memproduksi barang dan memperkerjakan tenaga kerja sebanyak 5 - 19 orang, 2) masalah yang didientifikasi adalah permasalahan yang muncul dan harus dihadapi oleh pengusaha $/$ pengrajin industri kecil pascagempa bumi, dan 3) periode pascagempa bumi ditentukan mulai dari periode waktu 27 Mei 2006 sampai dengan akhir bulan Agustus 2006.

\section{ANALISIS HASIL DAN PEMBAHASAN}

Pada bagian ini disajikan pembahasan hasil survei yang meliputi: (1) Komposisi kerusakan akibat gempa. (2) Bentuk kekhawatiran pengusaha/pengrajin. (3) Kebutuhan pengusaha/pengrajin. (4). Perkiraan pemulihan usaha (recovery).

\subsection{Komposisi Kerusakan}

Hasil survei menunjukkan bahwa sebagian responden mengalami kerusakan bangunan tempat menjalankan usaha. Sebanyak $27,14 \%$ reponden (19 pengusaha / pengrajin) mengalami kerusakan bangunan (Tabel 2). Dari kerusakan bangunan tempat menjalankan usaha tersebut, sebagian besar mengalami kerusakan dengan kategori berat dan sedang (92,86\%) dan sisanya mengalami rusak ringan.

Tabel 2

Komposisi Kerusakan

\begin{tabular}{|c|c|c|}
\hline No. & Jenis Kerusakan & Keterangan \\
\hline 1. & Potensi pasar & $30,00 \%$ \\
\hline 2. & Bangunan & $27,14 \%$ \\
\hline 3. & Alat / sarana produksi & $20,00 \%$ \\
\hline 4. & Bahan baku / input & $17,14 \%$ \\
\hline 5. & Lainnya & $5,72 \%$ \\
\hline & Jumlah & $100,00 \%$ \\
\hline
\end{tabular}

Sumber: Hasil survei (diolah) 
Dari sisi kerusakan alat / sarana produksi, ternyata sebanyak 20,00\% responden (14 responden) mengalami hal tersebut. Kerusakan terjadi pada alat produksi seperti mesin atau alat bantu produksi $(71,43 \%)$, juga terjadi pada sarana transportasi seperti mobil dan sepeda motor $(28,57 \%)$. Kerusakan pada alat produksi dan sarana transportasi sebagian besar termasuk dalam kategori ringan $(90,00 \%)$.

Kerusakan juga terjadi pada bahan baku, baik bahan baku pokok maupun bahan baku pembantu. Kerusakan bahan baku dialami oleh 17,14\% responden (12 responden). Jika diteliti lebih jauh, dari $17,14 \%$ responden yang mengalami kerusakan bahan baku sebanyak $66,67 \%$ responden yang mengalami kerusakan bahan baku pokok/utama. Dari sejumlah tersebut sebagian besar mengalami kerusakan dengan kategori ringan (75,00\%).

Hal lain yang dirasakan oleh pengusaha / pengrajin pascagempa adalah kerusakan atau kerugian yang berkaitan dengan potensi pasar dari barang yang mereka produksi ${ }^{5}$. Secara keseluruhan kerugian potensi pasar mencapai 30,00\% (21 responden). Kerugian tersebut mencakup penurunan jumlah barang yang diproduksi dan penurunan jumlah penjualan. Sebanyak $38,10 \%$ respon mengalami penurunan jumlah barang yang diproduksi, sedangkan yang mengalami penurunan nilai penjualan sebanyak $61,90 \%$ responden.

Hasil survei ini sejalan dengan survei dilakukan oleh PPE Fakultas Ekonomi UMY dan PPE Fakultas Ekonomi UAD (Bank Indonesia, 2006) serta Sri Susilo dan Krisnadewara (2006). Pengertian sejalan dalam hal ini adalah hasil survei komposisi kerusakan sama dalam urutan $I$ ranking-nya, yaitu potensi pasar, bangunan, alat/sarana produksi, bahan baku/input, dan lainnya. Perbedaannya hanya pada besaran (magnitude) persentasenya dan selisih perbedaan tersebut tidak banyak.

\subsection{Bentuk Kekhawatiran}

Bencana gempa bumi yang menimpa pengusaha / pengrajin industri kecil menimbulkan kekhawatiran, karena bencana tersebut mengakibatkan kerusakan pada sebagian peralatan produksi dan bahan baku serta infrastruktur ekonomi (lihat juga Bank Indonesia, 2006). Bentuk atau jenis kekhawatiran yang dirasakan oleh responden kehilangan pasar / pelanggan, meningkatnya biaya produksi, tidak mampu membayar kewajiban finansial, dan terpaksa melakukan PHK terhadap karyawan.

Jumlah responden yang mengkhawatirkan penurunan jumlah pelanggan / konsumen sebanyak 34,29\% atau sebanyak 24 responden (Tabel 3). Penurunan jumlah pelanggan I konsumen terjadi karena: (1) berhentinya kegiatan produksi, sehingga pelanggan mencari produsen / penjual dari daerah lain, dan (2) pelanggan / konsumen masih enggan datang ke wilayah terjadinya gempa.

Bentuk Kekhawatiran Pengusaha / Pengrajin

\begin{tabular}{|c|c|c|}
\hline No. & Bentuk Kekhawatiran & Keterangan \\
\hline 1. & Kehilangan pasar / pelanggan & $34,29 \%$ \\
\hline 2. & Proses produksi dan distribusi terganggu & $22,86 \%$ \\
\hline 3. & Tidak mampu membayar kewajiban finansial & $17,14 \%$ \\
\hline 4. & $\begin{array}{l}\text { Terpaksa melakukan PHK karyawan / Mengurangi } \\
\text { jam kerja karyawan }\end{array}$ & $14,29 \%$ \\
\hline 5. & $\begin{array}{c}\text { Tidak mampu melanjutkan usaha } \\
\text { Jumlah }\end{array}$ & $\begin{array}{c}11,42 \% \\
100,00 \%\end{array}$ \\
\hline
\end{tabular}

Sumber: Hasil survei (diolah)

5 Dengan berhentinya produksi mereka tidak mampu melayani permintaan pasar, sehingga dimungkinkan pembeli atau pelanggan berpindah ke produsen di sentra industri lain yang tidak mengalami musibah gempa bumi. 
Bentuk kekhawatiran lain yang muncul di kalangan pengusaha / pengrajin yang terpilih menjadi responden adalah proses produksi dan distribusi terganggu. Jumlah responden yang khawatir akan meningkatnya biaya produksi sebanyak 22,86\% (16 responden). Kekhawatiran ini terkait dengan kerusakan yang terjadi pada sarana atau peralatan produksi serta sarana transportasi yang dimiliki responden.

Dengan berhentinya proses produksi atau penurunan jumlah proses produksi tentu akan berpengaruh terhadap pendapatan. Kondisi tersebut pada gilirannya akan mengurangi kemampuan pengusaha / pengrajin untuk membayar kewajiban finansial terhadap pihak lain (Sri Susilo dan Krisnadewara, 2006). Jumlah responden yang mengkhwatirkan hal tersebut sebanyak $17,14 \%$. Selanjutnya kekhawatiran lain yang muncul adalah melakukan pemutusan hubungan kerja (PHK) karyawan atau setidaknya mengurangi jam kerja karyawan. Jumlah responden yang mengkhawatirkan masalah tersebut mencapai $14,29 \%$ atau sebanyak 10 responden.

Dampak gempa yang menimbulkan kerusakan bangunan serta prasarana dan sarana produksi menjadi beban yang harus ditanggung oleh pengusaha / pengrajin industri kecil.

Dari 70 responden ternyata sebanyak 8 responden $(11,42 \%)$ merasa tidak mampu menanggung kerugian akibat gempa dan melakukan investasi kembali, dengan kata lain merasa tidak mampu meneruskan usahanya. Dalam kaitan dengan hal tersebut, studi Sri Susilo dan Krisnadewara (2006) menemukan $6 \%$ responden menyatakan tidak mampu melanjutkan usahanya.

\subsection{Kebutuhan Pengusaha/Pengrajin}

Pascagempa bumi yang terjadi pada tanggal 27 Mei 2006, pengusaha / pengrajin industri kecil yang menjadi responden tentu memiliki prioritas kebutuhan yang harus dipenuhi. Jenis kebutuhan mendesak yang dirasakan oleh responden adalah perbaikan bangunan, baik untuk melaksanakan proses produksi maupun bangunan yang berfungsi sebagai outlet untuk memasarkan hasil produksi (showroom). Jumlah responden termaksud sebanyak $48,57 \%$ atau sebanyak 34 responden. Hasil survei PPE Fakultas Ekonomi UMY dan PPE Fakultas Ekonomi UAD (Bank Indonesia, 2006) menemukan 56\% responden menyatakan perbaikan bangunan untuk usaha adalah prioritas kebutuhan mereka, sedangkan hasil survei Sri Susilo dan Krisnadewara (2006) menemukan angka sebesar 48\%. Dengan demikian dari ketiga hasil survei tersebut dapat dikatakan hasil besaran persentasenya tidak jauh berbeda, sedangkan dari sisi urutan / ranking adalah sama yaitu pada urutan yang pertama. Berdasarkan hal ini, maka pengusaha / pengrajin yang menjadi korban gempa dapat dikatekan mempunyai prioritas kebutuhan yang sama, yaitu segera memperbaiki bangunan untuk usaha mereka.

\begin{tabular}{clc}
\multicolumn{3}{c}{ Tabel 4 } \\
\multicolumn{3}{c}{ Kebutuhan Pengusaha / Pengrajin } \\
\hline No. & \multicolumn{1}{c}{ Jenis Kebutuhan } & Keterangan \\
\hline 1. & Perbaikan bangunan untuk usaha & $48,57 \%$ \\
2. & Perbaikan / pengadaan alat produksi & $22,86 \%$ \\
3. & Tambahan modal usaha & $17,14 \%$ \\
4. & Keringanan pinjaman & $10,00 \%$ \\
5. & Lain-lain & $1,43 \%$ \\
& & $\mathbf{1 0 0 , 0 0 \%}$ \\
\hline
\end{tabular}

Sumber: Hasil survei (diolah)

Selanjutnya responden yang menyatakan kebutuhan mendesaknya adalah perbaikan I pengadaan alat produksi sebanyak 22,86\% (Tabel 4). Temuan ini jika dibandingkan dengan survei PPE Fakultas Ekonomi UMY dan PPE Fakultas Ekonomi UMY (Bank Indonesia, 2006) hasilnya ada perbedaan. Hasil survei kedua lembaga tersebut menemukan angka sebesar $11 \%$. Kelompok responden yang termasuk ini pengusaha / pengrajin adalah mereka yang alat 
produksinya perlu diperbaiki atau bahkan diganti dengan yang baru, meskipun bangunan tempat usahanya juga mengalami kerusakan namun masih dapat dipergunakan untuk melaksanakan kegiatan produksi / kerusakan kategori ringan (Bank Indonesia, 2006).

Selain kebutuhan tersebut di atas, sebagian pengusaha / pengrajin industri kecil yang menjadi responden merasakan perlunya tambahan modal usaha $(17,14 \%)$ dan keringanan pinjaman (10,00\%). Dari hasil wawancara mendalam dengan wakil pengusaha / pengrajin, mereka mengharapkan bantuan tambahan modal dari perbankan, lembaga swadaya masyarakat (LSM), BUMN, dan juga pihak pemerintah ${ }^{6}$. Bantuan modal baik dari perbankan dan pemerintah yang mereka harapkan adalah kredit khusus dengan bunga relatif rendah dan bersifat jangka panjang atau grace-period cukup lama (lihat Kurniawan, 2006).

Untuk keringanan kewajiban pinjaman / finansial, responden berharap pihak perbankan dapat menghapus pinjaman / memberi potongan pinjaman atau setidaknya melakukan penjadwalan kembali bagi pengusaha / pengrajin yang mengalami kerusakan bangunan dan alat produksi kategori berat dan sedang. Dari asosiasi pengusaha mengharapkan pemerintah dapat memberikan keringanan terhadap pembayaran listrik dan pajak (lihat juga misalnya Sugiyanto, 2006).

\subsection{Kemampuan Recovery}

Kemampuan untuk recovery dari pelaku bisnis, sangat terkait dengan kemampuan untuk melakukan rehabilitasi atau rekonstruksi terhadap segala kerusakan yang telah dialami, dalam hal ini terkait dengan kemampuan finansial yang dimiliki (Kurniawan, 2006) ${ }^{7}$. Hasil survei menunjukkan bahwa $85,71 \%$ pelaku usaha memiliki tabungan (60 responden), namun demikian kemampuan untuk mendanai proses rehabilitasi dari tabungan yang dimiliki ini mayoritas responden (70\%) menyatakan hanya sanggup mendanai kurang dari $25 \%$ dari seluruh kebutuhan dana. Hal ini mengindikasikan bahwa suntikan dana sebagai modal kerja menjadi kebutuhan yang sangat mendesak.

Lebih jauh dikatakan oleh pelaku usaha, kebutuhan dana ini sangat urgent diperlukan, mengingat saat ini sebagian besar sektor industri memiliki outstanding purchase order yang harus segera dipenuhi dan dikirimkan kepada para pembeli. Berhentinya proses produksi ini tidak dapat dibiarkan terhanti dalam jangka waktu terlalu lama. Apabila usaha tidak segera berjalan maka dikhawatirkan akan terjadi potensi kehilangan pasar yang sangat besar bagi industri di Kabupaten Klaten. Hal ini terungkap dari dampak yang paling dikhawatirkan oleh pelaku usaha saat ini adalah potensi kehilangan pasar sebesar 30\% (lihat Tabel 2).

Hasil survei menunjukkan bahwa perkiraan terhadap recovery dari masing-masing responden relatif bervariasi (lihat Tabel 5). Jumlah responden yang memperkirakan usahanya akan pulih dalam kurun waktu kurang dari 3 bulan sebanyak 6 responden (8,57\%). Responden ini dapat dikatakan berpandangan sangat optimis. Hal ini dimungkinkan jika pengusaha / pengrajin kecil tersebut: (1) kerusakan bangunan dan fasilitas produksi termasuk dalam kategori ringan, (2)

\footnotetext{
${ }^{6}$ Berkaitan dengan kredit perbankan, Bank Indonesia telah mengeluarkan Peraturan Bank Indonesia No. 8/10/PBI/2006. Regulasi tersebut pada dasarnya perbankan memberikan kemudahan bagi pengusaha / pengrajin korban gempa (Kuncoro, 2006b). Salah satu kemudahan termaksud adalah bank dan BPR diperkenankan memberikan kredit baru kepada debitur di daerah gempa meskipun kredit awalnya telah bermasalah karena adanya gempa tersebut Dari informasi di lapangan ternyata kemudahan fasilitas kredit tersebut belum sesuai dengan harapan pengusaha / pengrajin yang menjadi responden dalam riset ini.

7 Pemulihan usaha diperkiarakan memakan cukup lama, selain karena faktor dana untuk rehabilitasi yang diperkirakan cukup besar, faktor lain adalah tenaga kerja terampil di sentra-sentra industri di wilayah gempa mulai dilirih oleh pengusaha / pengrajin di luar wilayah Yogyakarta dan klaten (Fatchiati, 2006). Kemampuan dan proses percepatan recovery juga dipengaruhi oleh motivasi untuk bangkit kembali secara mandiri dari para pengusaha / pengrajin industri kecil (Sugihandari dan Sugiya, 2006).
} 
sudah mempunyai pelanggan tetap dan pesanan untuk jangka waktu tertentu, dan (3) mempunyai modal / tabungan yang cukup untuk mendukung usahanya.

Tabel 5

Perkiraan Recovery Usaha

\begin{tabular}{|c|c|c|}
\hline No. & Perkiraan / Estimasi & Keterangan \\
\hline 1. & $<3$ bulan & $8,57 \%$ \\
\hline 2. & Antara $3-6$ bulan & $14,29 \%$ \\
\hline 3. & Antara $6-12$ bulan & $28,57 \%$ \\
\hline 4. & $>1$ tahun & $42,85 \%$ \\
\hline 5. & Tidak tahu & $5,72 \%$ \\
\hline & Jumlah & $100,00 \%$ \\
\hline
\end{tabular}

Sumber: Hasil survei (diolah)

Selanjutnya responden yang mempunyai estimasi usahanya akan pulih dalam kurun waktu 3 - 6 bulan sebanyak 14,29\%, sedangkan yang mempunyai perkiraan antara 6 - 12 bulan sebanyak $28,57 \%$ (Tabel 5). Kemudian responden yang memperkirakan usahanya akan pulih kembali dalam jangka waktu lebih besar dari 1 tahun sebanyak 42,85\% atau sebanyak 30 responden. Kemudian sebanyak 4 responden (5,72\%) menyatakan tidak tahu kapan usahanya akan pulih seperti sebelum terjadinya gempa. Informasi dari dinas terkait dan asosiasi pengusaha di Kabupaten Klaten menyatakan bahwa secara keseluruhan diperkirakan industri di wilayah akan pulih dalam jangka waktu sekitar 3 tahun $^{8}$.

\section{PENUTUP}

Masalah yang dihadapi pengusaha / pengrajin dalam riset ini lebih dari sisi penawaran dari pada sisi permintaan ${ }^{9}$. Untuk itu yang lebih penting adalah upaya percepatan pemulihan kembali (recovery) dari usaha, dan hal tersebut diawali dengan melakukan kegiatan produksi. Bagi pengusaha / pengrajin korban gempa suntikan berupa bantuan modal menjadi sangat berarti. Dengan tambahan modal maka berbagai keterbatasan dalam kegiatan produksi dapat dikurangi I ditekan, sehingga aktivitas produksi akan lebih lancar dan pada gilirannya pasar dapat dilayani dengan baik.

Keberhasilan upaya percepatan pemulihan usaha bagi industri kecil juga tergantung dari kemauan dari pengusaha / pengrajin untuk segera bangkit dan bekerja kembali. Prinsip swadaya dan gotong royong harus tertanam dalam diri mereka. Selanjutnya juga dibutuhkan keterpaduan semua stake-holders, baik pemerintah, perbankan, asosiasi pengusaha, BUMN, LSM, pemasok, dan konsumen, untuk membantu dan mendukung proses pemulihan usaha industri kecil korban gempa.

Dari segi metode, keterbatasan riset ini terletak pada besarnya sampel (sample size) atau jumlah responden dan cakupan kelompok industri yang diteliti yang jumlah / cakupannya terbatas.

8 Hasil survei ini sejalan dengan pernyataan Kepala Disperindagkop dan Penanaman Modal Kabupaten Klaten diperkirakan membutuhkan waktu 3 tahun untuk memulihkan dan menormalkan kembali UMKM di wilayah Klaten (Eki, 2006). Kepala Disperindagkop Kabupaten Bantul dan Kepala Disperindagkop Propinsi DIY menyatakan bahwa industri di wilayah tersebut akan diperkirakan akan pulih dalam waktu 2-3 tahun (Anonim, 2006a; Anonim, 2006b). Dengan demikian perkiraan waktu pemulihan industri di Kabupaten Klaten dengan di Propinsi DIY tidak berbeda.

9 Berbeda dengan kasus "Bom Bali" maka industri kecil lebih terkena dampak lebih dari sisi permintaan. Untuk kasus "Krisis Ekonomi 1998" maka pada umumnya industri kecil terkena dampaknya baik dari sisi permintaan dan penawaran. 
Untuk memperoleh informasi dan data yang lebih mendalam, maka sebaiknya riset sejenis di masa mendatang disertai dengan kegiatan focus group discussion (FGD).

\section{DAFTAR PUSTAKA}

Anonim, (2006a), "Tahun 2008, UMKM di DIY Dapat Pulih", Kedaulatan Rakyat, 27 September 2006, pp.16.

Anonim, (2006b), "Kembali ke Semula Butuh 2-3 Tahun: Industri Kerajinan Bantul Optimis Bangkit", Kedaulatan Rakyat, 27 Juli 2006, pp. 14.

Ari/Litbang Kompas, (2006), "Industri Kecil Harus Segera Bangkit", Kompas, 8 Juni 2006, diakses dari http://www.kompas.co.id/kompas-cetak/0606/8/jateng/36890.htm pada tanggal 20 September 2006.

Bank Indonesia, (2006), Laporan Perkembangan Perekonomian Daerah Istimewa Yogyakarta: Triwulan II - 2006, Kantor Bank Indonesia Yogyakarta, Juli 2006.

Bappenas, Pemda Propinsi DIY, Pemda Propinsi Jawa Tengah, dan Mitra Internasional, (2006), Preliminary Damage and Lost Asesstment Yogyakarta and Central Java Natural Dissaster, June, 2006, diakses dari http://rehabyogyajateng.bappenas.go.id pada tanggal 22 Agustus 2006.

Eki, (2006), "Tiga Tahun, Pemulihan UMKM", Kompas, 14 Juni 2006, diakses dari http://www.kompas.co.id/kompas-cetak/0606/14/jateng/37130.htm pada tanggal 20 September 2006.

Fatchiati, N. (2006), "Sentra Industri, Ujung Tombak Mikroekonomi yang Terkoyak", Kompas, 30 Juni 2006, diakses dari http://www.kompas.co.id/kompas-cetak/0606/30/jogja/25942.htm pada tanggal 20 September 2006.

Hanke, J.E., dan Reitsch, A.G., (1998), Business Forecasting, Sixth Edition, Prentice-Hall International Ltd., London.

Kountur, R., (2003), Metode Penelitian Untuk Penelitian Skripsi dan Tesis, Cetalan 1, Penerbit PPM, Jakarta.

Kuncoro, M., (2006a), "Membangkitkan UKM Pascagempa", Kedaulatan Rakyat, 17 Juni 2006, diakses dari http://www.mudrajad.com pada tanggal 24 September 2006.

Kuncoro, M., (2006b), "Ancaman Pertumbuhan Negatif", Kedaulatan Rakyat, 17 September 2006, diakses dari http://www.mudrajad.com pada tanggal 28 Oktober 2006.

Kuncoro, M., (2003), Metode Riset Untuk Bisnis \& Ekonomi: Bagaimana Meneliti \& Menulis Tesis?, Cetakan 1, Erlangga, Jakarta.

Kurniawan, A.B., (2006), "Penilaian Kerusakan \& Kerugian Serta Identifikasi Kebutuhan Industri Akibat Gempa Tektonik 27 Mei 2006 Di Daerah Istimewa Yogyakarta," Executive Summary, KP2EY Yo Bangkit, Yogyakarta. (tidak dipublikasikan). 
Pemda Propinsi DIY dan Pemda Propinsi Jateng, (2006), Atlas Kawasan Gempa Bumi 27 Mei 2006, Edisi 27 Juni 2006, diakses dari http://rehabyogyajateng.bappenas.go.id pada tanggal 22 Agustus 2006.

Sekaran, U., (2003), Research Methods for Business A Skill-Building Approach, Fourth Edition, John Wiley \& Sons, Inc., Singapore.

Singarimbun, M., dan Effendi, S., (Editor), (1989), Metode Penelitian Survei, Edisi Revisi, Cetakan 1, LP3ES, Jakarta.

Sri Susilo, Y., (2005), "Strategi Survival Usaha Mikro Kecil (Studi Empiris Pedagang Warung Angkringan di Yogyakarta)", Telaah Bisnis, Vol. 6 (2), Desember 2005, pp. 161 - 178

Sri Susilo, Y., dan Krisnadewara, P.D., (2006), "Strategi Survival Industri Kecil Pascagempa Bumi: Kasus Pada Beberapa Industri di Propinsi Daerah Istimewa Yogyakarta", Makalah, Seminar Akademik Ekonomik III, Program Pascasarjana IImu Ekonomi FEUI dan Bank Indonesia, 6 - 7 Desember 2006. (Forthcoming)

Sri Susilo, Y. , dan Sutarta, A.E., (2004), "Masalah dan Dinamika Industri Kecil Pasca Krisis Ekonomi", Jurnal Ekonomi Pembangunan, Vol. 9 (1) Juni 2004, pp. 79 - 90

Sri Susilo, Y., dan Sri Handoko, B., (2002), "Dampak Krisis Ekonomi Terhadap Kinerja Sektor Industri: Pendekatan Model Keseimbangan Umum Terapan INDORANI", Jurnal Ekonomi \& Bisnis Indonesia, Vol. 17 ( 3), Juli 2002, pp. 243 - 257

Sugihandari, dan Sugiya, A. (2006), "Mesti Dampak Gempa Pahit, Harus Segera Bangkit", Kompas, 21 Juni 2006, diakses dari http://www.kompas.co.id/kompascetak/0606/21/jateng/37461. htm pada tanggal 20 September 2006.

Sugiyanto, C. (2006), "The Economic Impact of the May 2006 Earthquake in Yogyakarta, with Special Reference to Manufacturing Activities," Material Presentation, PSEKP UGM Yogyakarta dan Indonesia Project, RSPAS, ANU, August 9, 2006, diakses dari http://paue.ugm.ac.id pada tanggal 20 September 2006. 